\title{
Serum Glucose Level and Hemoglobin Concentration in Third Trimester of Pregnancy
}

\author{
Sumaira Sufrin ${ }^{1}$, Akhtarun Nessa² ${ }^{2}$ Md. Tazul Islam³
}

\begin{abstract}
Background : Pregnancy is a state of physiological adaptations to accommodate the needs of the developing fetus. Elevated blood glucose during pregnancy could lead to gestational diabetes and anemia could cause intercurrent infection. Objective: To assess the serum glucose level \& hemoglobin concentration in third trimester of pregnancy in order to find out the risk of gestational diabetes and physiological anemia. Method: This cross-sectional study was carried out in the Department of Physiology Mymensingh Medical College, Mymensingh, between the period of July, 2013 to June,2014. One hundred pregnant women in their third trimester of pregnancy aged 18-35years were enrolled in study group and age matched 100 healthy non-pregnant women were control group. Random serum glucose was estimated by GOD-PAP method and hemoglobin concentration was measured by cyanmethemoglobin (CMG) method. Data were analyzed by student's un paired $t$ test and chi square test. Result: Mean serum glucose level $(6.76 \pm 1.72 \mathrm{mmol} / \mathrm{L})$ was significantly higher and hemoglobin concentration $(8.21 \pm 1.23 \mathrm{~g} / \mathrm{dl})$ was significantly lower in pregnant women than non-pregnant women. Increased frequency of high glucose (38\%) and low $\mathrm{H} \mathrm{b}(88 \%)$ was found in pregnant women in third trimester. Conclusion: This study concludes altered glucose metabolism may lead to gestational diabetes as well as physiological anemia may be exaggerated in third trimester of pregnancy.
\end{abstract}

Key words- Serum Glucose level, Hemoglobin concentration, Third Trimester of Pregnancy.

J Bangladesh Soc Physiol. 2015, December; 10(2): 67-70

For Authors Affiliation, see end of text.

http://www.banglajol.info/index.php/JBSP

\section{Introduction}

$\mathbf{T}$ he pregnant women experiences physiological changes to support fetal growth and development. During pregnancy, glucose tolerance is normal or slightly improved and peripheral (muscle) sensitivity to insulin and hepatic basal glucose production is normal. ${ }^{1}$

Glucose metabolism changes during normal pregnancy, reflecting altered glucose handling by the mother and nutritional demands of the developing fetus. In normal women, marked

Received June 2015;

Accepted August 2015 insulin resistance develops, particularly by the second half of the pregnancy. Fasting glucose decreases slightly, while blood glucose may be increased post-prandially. ${ }^{2}$

There was however, some loss of homeostasis as shown by lower preprandial and higher postprandial glucose levels. ${ }^{3,4,5}$

Gestational diabetes is a condition of elevated blood glucose level during pregnancy which is associated with increased fetal insulin and thus increased fetal size and bad obstretic out come. ${ }^{6}$ 
During pregnancy there is increase in total blood volume with increased both plasma and erythrocyte volumes. Pregnant women are at risk of physiological anemia because of relative increase of plasma volume to RBC volume ${ }^{7}$.

But presentation of clinically evident anemia in third trimester is common due to demand for micronutrients is maximum in third trimester, which may attribute to the high prevalence of anemia 8,9 .

Severe maternal anemia may cause intra-uterine death of fetus (IUD) if mother develop severe anoxaemia. Anemia with $\mathrm{Hb}<8 \mathrm{gm} / \mathrm{dl}$ has seem to be associated with birth weight values that are 200-300 gm lower than in women with $>10 \mathrm{gm} / \mathrm{dl}$ Hemoglobin.$^{10}$ Very few publication on $\mathrm{Hb}$ and glucose profile in third trimester are available. Therefore, this study has been designed to evaluate glycemic profile and hemoglobin status in third trimester of pregnancy.

\section{Methods}

This cross-sectional study was carried out in the Department of Physiology Mymensingh Medical College, Mymensingh between the period of July, 2013 to June, 2014. One hundred pregnant women without complication in their third trimester of pregnancy aged 18-35years were enrolled in study group and aged matched 100 healthy non-pregnant women served as control group. Study subjects were selected by following random sampling procedure from Mymensingh medical college hospital and the protocol of this study was approved by Instituitional Ethics Committee (IEC) of Mymensingh Medical college. All the subjects were free from diabetes,hypothyroidism, cushing syndrome, polycystic ovary, renal \& cardiovascular disorder. Before recruitment aim, benefit and procedure of study was explained and their informed written consent from each subject were taken. Thorough physical examination of all subjects were done. Then under asceptic precaution $5 \mathrm{ml}$ blood samples were drawn from anticubital vein. Serum was prepeared by ultracentrifugation. Random blood glucose livel was estimated by GOD-PAP method and hemoglobin concentration was estimated by cyanmethemoglobin (CMG) method by a colorimeter. The statistical analysis done by Student's Unpaired ' $t$ ' test. and chi square test as applicable.

\section{Results}

Mean \pm SE serum glucose level was significantly $(\mathrm{p}<0.001)$ higher \& mean hemoglobin concentration was significantly $(p<0.001)$ lower in third trimester of pregnancy than those of nonpregnant women ( Table I). In third trimester $39 \%$ pregnant women were found with elevated glucose and $88 \%$ were found with low hemoglobin levels whereas only $4 \%$ and 58\% of non pregnant had elevated glucose and. low $\mathrm{Hb}$ level respectively. The difference was statistically significant. $(p<0.001)$ (Table II).

Table I: Serum glucose and Hemoglobin concentration in different groups $(n=200)$

\begin{tabular}{lcc}
\hline Parameters & $\begin{array}{c}\text { Non pregnant } \\
(\mathrm{n}=100)\end{array}$ & $\begin{array}{c}\text { Pregnant }(\text { third } \\
\text { trimester })(\mathrm{n}=100)\end{array}$ \\
\hline $\begin{array}{l}\text { Serum glucose } \\
(\mathrm{mmol} / \mathrm{L})\end{array}$ & $6.91 \pm 0.51 .72^{* * *}$ \\
$\begin{array}{l}\text { Hemoglobin } \\
(\mathrm{gm} / \mathrm{L})\end{array}$ & $9.76 \pm 0.64$ & $8.21 \pm 1.23^{* * *}$ \\
\hline
\end{tabular}

Data expressed as Mean \pm SE. Statistical analysis were done by student's unpaired t test $* * * \mathrm{p}<0.001$

Table II: Frequency of higher glucose and low hemoglobin level $(n=100)$

\begin{tabular}{lcccc}
\hline Parameters & \multicolumn{2}{c}{$\begin{array}{c}\text { Non } \\
\text { pregnant }\end{array}$} & \multicolumn{3}{c}{$\begin{array}{c}\text { Pregnant } \\
(\mathrm{n}=100)\end{array}$} \\
& no & $\%$ & no & $\%$ \\
\hline $\begin{array}{l}\text { Serum glucose } \\
(>7 \mathrm{mmol} / \mathrm{L})\end{array}$ & 04 & 4 & 39 & $39^{* * *}$ \\
$\begin{array}{l}\text { Hemoglobin } \\
(10 \mathrm{gm} / \mathrm{L})\end{array}$ & 58 & 58 & 88 & $88^{* * *}$ \\
\hline
\end{tabular}

Chi-square test analyzed statistical significance. $* * *$ $\mathrm{P}<0.001$ 


\section{Discussion}

Present study found high level of serum glucose in most of the of pregnant women in third trimester which was similar to others. ${ }^{18,19}$ Some investigator found glucose level is increased from the first trimester to last trimester. ${ }^{20}$

In late pregnancy insulin secretion can be stimulated 2-3 fold by nutrients compared with non-gravid state. This defect in the metabolic action of insulin may probably reside distal to the binding receptors of insulin, which are influenced by placental hormones, i.e human placental lactogen (HPL), estradiol, progesterones, and free cortisol. Glucose attains greater and more prolonged post-prandial elevation in late pregnancy. ${ }^{21}$

In a study, Homko Carol in 2001 found that during late pregnancy women with GDM were insulin resistant and had defective insulin secretion in response to moderate hyperglycemia. They suggested that GDM resulted from a failure of â cells to compensate for the increase in insulin resistance that occurred during late gestation. ${ }^{22}$

In this study, hemoglobin concentration of pregnant women of third trimester of pregnancy is lower than non-pregnant women of reproductive age and majority of pregnant had anemia comparable to $23,24,25$ Whereas, few investigator found hemoglobin concentration is highest in the first trimester, reaches its lowest point in the second trimester and begin to rise again in the third trimester. ${ }^{26}$

Khoigani Masoomeh Goodrazi in 2012 concluded in their study that gestational age is the main factor associated with the hematocrit values, so that increase in gestational age leads to decrease in hematocrit. It seems that hemoglobin also decrease with increase gestational age ${ }^{19}$.

\section{Conclusion}

This study concludes that serum glucose level in third trimester of pregnancy may increase.
Hemoglobin concentration is decreased in third trimester of pregnancy thus aggravating preexisting physiological anemia of pregnancy.

\section{Authors Affiliation}

1. "Sumaira Sufrin Lecturer physiology, Jamalpur medical college, Jamalpur.

Email: sumairasufrin0079@yahoo.com

2. Akhtarun Nessa Professor. \& Head of the department of Physiology, Mymensingh Medical College, Mymensingh

E.mail-nessa_@yahoo.com

3. Md. Tazul Islam. M.O Fulbaria Upazilla Health complex, Mymensingh

E.mail- tazvirrio@yahoo.com

${ }^{*}$ For correspondance

\section{Conflict of interest: none}

\section{References}

1. Catalano PM, Tyzbir ED, Wolfe RR. Carbohydrate metabolism during pregnancy in control subjects and women with gestational diabetes. Am J Physiol 1993, 264 : E60-E67.

2. Frier B.M, Fisher M. Diabetes Mellitus. Colledge NR.: Walker BR.: Ralston SH. Davidson's Principles \& Practice of Medicine. $21^{\text {st }}$ ed. London, NewYork : Churchill Livingston ELSEVIER, 2010. p. 805, 806, 815, 816, 798 .

3. Freinkel, N., On the Nature and Treatment of Diabetes, ed. B.S. Liebel and G.A. Wrenshall. Amsterdam: Excerpta Medica Foundation; 1965. p. 679.

4. Felig P., American Journal of Clinical Nutrition. 1973; $26: 998$.

5. Burt R. L., and Davidson I. W. F.,Obstetrics and Gynaecology. 1974; 43: 161.

6. Frier B.M, Fisher M. Diabetes Mellitus. Colledge NR.: Walker BR.: Ralston SH. Davidson's Principles \& Practice of Medicine. $21^{\text {ste }}$. London, NewYork : Churchill Livingston ELSEVIER, 2010. p. 805, 806, $815,816,798$.

7. Chellakooty M, Vangsgaard K, Larsen T, Scheike T, Falck-Larsen J, Legarath J, Andersson AM, Main KM, Skakkeback NE, Juul A: A longitudinal study of intrauterine growth and the placental growth hormone (GH)-Insulin like growth factor-I axis in maternal circulation: association between placental growth hormone and fetal growth. J Clin Endocrinol Metab 2004; 89: 384-391. 
8. Redman CW, Sergent IL: pre-eclampsia, the placenta and the maternal systemic inflammatory response $-\mathrm{a}$ review. Placenta 2003; 24 (Suppl.A): S21-S27.

9. Gyton A.C, Hall JE.Pregnancy and lactation. Gyton and Hall Text book of Medical Physiology. $12^{\text {th }}$ ed. India : Elsevier India private limited, 2011. p. 1010: $1011,1003$.

10. Blot DD, Tehernin G. Iron deficiency in pregnancy : effects on the newborn. Curr Opin Hematol 1999, 6 : $65-70$.

11. Seshiah V, Balaji V, Balaji M.S, Paneerselvam A, Arthi T, Thamizharasi M, Datta M. Gestational Diabetes Mellitus manifest in all trimesters of pregnancy. Diabetes Research and Clinical practice. 2007; 77: 482-484.

12. Islam N, Chowdhury S, Kazal RK, Rahman R, Parveen HH, Begum KF, Chowdhury SB. Serum Ferritin and Gestational Diabetes Mellitus: A Case Control Study. Journal of Bangladesh College of Physicians and Surgeons. Oct, 2012; 30(4): 205-210.

13. Ekhator C.N, Ebomoyi M.I. Blood glucose and serum lipid profiles during pregnancy. African Journal of Diabetes Medicine. May, 2012; 20(1): 16-19.

14. Dutta D.C. Physiological changes during pregnancy. Konar Hiralal. Text Book of Obstetrics including perinatology and contraception. $6^{\text {th }}$ ed. Calcutta 700
009 (India): New central book agency(P) Ltd, 2006. p.46, 52, 221, 51, 263.

15. Khoigani M.G, Goli S, Zahed A.H. The relationship of hemoglobin and hematocrit in the first and second half of pregnancy with pregnancy outcome. Iranian Journal of Nursing and Midwifery Research. Feb, 2012; 17(2): 165-170.

16. Wahed F. Studies on hemoglobin, packed cell volume, serum iron and total iron binding capacity in first, second, and third trimesters of pregnancy with \& without iron supplementation.[dissertation]. [Mymensingh medical college] : Dhaka University. July, 2005.

17 Hacker N, Moore J: Essential of Obstetrics and Gynecology. $2^{\text {nd }}$ ed. W.B Saunders Company, Pennsylvania; 1992.

18 Al-Farsi YM, Brooks D.R, Werler M.M, Cabral H, AlShafei M.A, Wallenburg H.C. Effect of high parity on occurrence of anemia in pregnancy: a cohort study. BMC Pregnancy and Childbirth 2011; 11: 7.

19. James T.R, Reid H.L, Mullings A.M. Standards for hematological indices in pregnancy applicable across populations:an ev aluation in healthy pregnant Jamaican women. BMC Pregnancy and Childbirth 2008; 8: 8doi: 10.1186/1471-2393-8-8.http:// www.biomedcentral.com/1471-2393-8-8. 